\title{
The Poverty of Apologism: The British Left, Feminism and the Islamic Right
}

\author{
Stephen Cowden * \\ *Correspondence: [hsx384@coventry.ac.uk]
}

There was once a time when if you went to a Marxist conference and heard Marx's oft-quoted words about religion being 'the sigh of an oppressed creature, the heart of a heartless world and... the opium of the people', it was because the speaker was attacking religious belief. The words were seen as a byword for a kind of Marxist atheism. In a way, this was itself an over simplification of what Marx was saying, which was not an argument for atheism as such. His point was rather that religious belief could not simply be dismissed as a 'delusion'; we needed to understand that the very suffering and pain in the lives of oppressed workers encouraged a belief in a better world, which was articulated through the language and structures

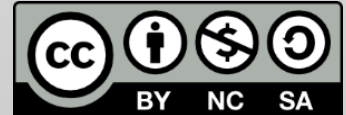

(C) Copyright: The Authors. This article is issued under the terms of the Creative Commons Attribution NonCommercial Share Alike License, which permits use and redistribution of the work provided that the original author and source are credited, the work is not used for commercial purposes and that any derivative works are made available under the same license terms. of religion. But Marx was also saying that the way religion dulled the pain of people's lives in its opiate-like manner also meant that it wasn't addressing the real problems - which he saw as those material conditions that caused that suffering and pain.

In my most recent experience of attending a Marxist conference - the 'Historical Materialism' conference in London in November 2015 - I was struck by the way that whenever I heard those words being quoted, as they were numerous times, it was as a defence of religious belief. There 
are several dimensions to how this strange turnaround has taken place. If we look at contemporary political theory within universities there has been a vast swath of material, coming out of Post-colonialism in particular, which has contributed to this change. Edward Said's 'Orientalism' was originally published in 1978 but his call for the reframing of the knowledges by which the 'West' understood the 'Orient' as 'a Western style for dominating, restructuring, and having authority over the Orient' (1990:3) have hugely influenced the shape of the debate. The Postcolonial theory inspired by this sees its mission as one of critically destabilising the categories of 'Western thought' - modernity, rationality, individualism which it characterises as tools for the subjugation of the colonial subject. These ideas have had a major impact within the academy, and while it there is not space here to evaluate this in detail here ${ }^{1}$, there is no question that has significantly impacted the perception of secularism. Once seen as a progressive default position, the doctrine of secularism has come to be understood as part and parcel of the Imperial Ideological State Apparatus, which 'the people' are fighting through the assertion of their subaltern religious subjectivities. While the presentation of secularism as a colonial imposition is not uniform within postcolonial theory, there is no doubt that these shifts have created a context in the humanities and social sciences where a defence of a secular politics can very easily lead one to be presented as promoting 'Western colonial thinking'.

The diminishing commitment to a secularism is equally reflected in the changing shape of left wing political activism in the UK. The key moment 
here was the mobilisation against the Iraq War in 2003, which saw the Stop the War Coalition (STWC) enter into an alliance with the Muslim Association of Britain (MAB). The latter group was dominated by a conservative form of Sunni Islam and there is evidence that sections of the leadership had significant links with the Muslim Brotherhood (House of Commons, 2015). In 2003 this coalition organised a highly successful demonstration in London involving two million people and in attempting to build on this popular opposition to the invasion of Iraq, the Socialist Workers Party (SWP) - the biggest far left group in the UK - formed the Respect Party in 2004. This was led by the ex-Labour MP George Galloway who broke with the Labour Party leadership over the Iraq war. While SWP members were the main force within Respect, the party's development meant that it relied on Muslim votes and activism to deliver electoral results. In the 2004 European elections their publicity described George Galloway as a 'Fighter for Muslims...teetotal, [with] strong religious principles about fighting injustice'; indeed Respect became an organisation which as Hannah Sell noted was primarily appealing to Muslims 'on the basis of their religion' (Sell, 2004). Worse than this the supposedly leftist Respect Party had ended up in an alliance with the most right wing and puritanically intolerant forms of Islam that in East London were actually attacking more progressive anti-fundamentalist versions of Islam (Bhatt, 2006, 98-99).

While Respect has now largely collapsed as a political force, the confusion on which this politics is based, not to mention its failure to 
interrogate questions of secularism, women's and LGBT rights, has unfortunately not. While there is no denying the intensity of racism being targeted at Muslim communities at the moment - expressed through far right political parties and movements like the Front National in France, Pergida in Germany and the English Defence League (EDL) and the United Kingdom Independence Party (UKIP) in the UK - it is not in any way clear why this this requires sections of the Left continue to politically ally themselves with and defend the Islamic religious right. It was exactly this politics I encountered at the Historical Materialism conference on 6-7 November 2015 at SOAS in London. This is a conference I have attended regularly and most of the conference this year was very good, as it generally is. However the session entitled 'Islamaphobia, Secularism and Feminism' left me deeply troubled about the dominance of this form of apologetics for the Islamic right and the way a younger generation of antiracist activists, justifiably concerned about anti-Muslim racism, have come to support this, while being entirely unaware of the way this politics involves the erasure not just of secularism, but of a whole history of feminist struggles against the religious control of women's lives and bodies.

The speakers in this session were Ian Birchall, former leading SWP member, a group presentation from David Miller, Nazarin Massoumi and Tom Mills, who have researched and written together on issues of Islamaphobia, and Nancy Lindisfarne, an anthropologist based at SOAS. Birchall's paper offered a critique of the French Left's support for the 
secularist concept of 'Laicite' (see Birchall, 2015) suggesting, somewhat strangely in my view, that there was nothing progressive about this. However this work is beyond the scope of my discussion here, which is primarily concerned with the material in the presentation entitled 'Contesting racialisation: Islamaphobic social movements and the battle of ideas' from Miller, Mills and Massoumi. This material represented a reiteration of an earlier piece the three published with Hilary Aked on the Open Democracy website entitled 'The Five Pillars of Islamaphobia' (Miller et.al July 2015). Their paper began by challenging writers such as Kenan Malik, Fred Halliday and Nira Yuval Davis for their rejection of the term 'Islamaphobia' on the basis that this conflates legitimate criticism of religious institutions and ideology with racist attacks against Muslims. According to Miller, Massoumi and Mills this criticism this criticism is itself 'Islamaphobic' and simply demonstrates the way 'secularist liberals' are colluding with anti-Islamic bigotry. They went on to characterise what they call the five pillars of Islamaphobia as:

1. The state and government counter terror apparatus

2. Far Right movements, particularly focussing on the 'Counter Jihad' movement

3. The Neoconservative right, with a particular focus on the Henry Jackson Society

4. The Zionist movement and Israeli state

5. The pro war left and new secularists. 
One might question the way this last grouping was presented as a single entity, but this was only one of many conflations here. In the group's discussion of the so-called 'new secularists', Southall Black Sisters (SBS) and British Muslims for a Secular Democracy (BMSD) were singled out for their 'Islamaphobia'. When I raised the question of how organisations like a committed anti-racist group like SBS could be reasonably described as 'Islamaphobic', Nazarin Massoumi replied that SBS was 'once progressive' but now 'supports the racist practices of the state' through its involvement in counter radicalisation strategies, by which I would assume she is referring to the UK Government's counter-radicalisation strategy, known as PREVENT. ${ }^{2}$, though the group failed to offer any evidence of what this involved and how it was substantively 'Islamaphobic'. Indeed it is revealing of the nature of this group's work that they see it as appropriate to place political groups like SBS and BMSD alongside MI5 and MOSSAD. This was a session with a young audience and one of the things I found frustrating was the way this whole focus on 'Islamaphobia' was so readily accepted by an audience almost entirely unaware of the work done by groups like Southall Black Sisters and Women Against Fundamentalism (see Dhaliwal and Yuval-Davis [2014] for an account of the latter).

The final speaker was Nancy Lindisfarne whose presentation was entitled 'Islamaphobia and Cultural Racism'. This was a version of a paper which she has published with Jonathon Neale on her site at Academia.edu (Lindisfarne and Neale, 2015). They argue that Islamic movements in the Middle East were 'resistance movements' to Western Oil Empires. While 
Lindisfarne does state that these movements are considerably less preferable than socialist or Marxist movements, she also depicts them as resistance movements that need to be supported by the Left nonetheless. When questioned about this, Lindisfarne went as far as to express critical admiration for ISIS' resistance stating 'you might not like everything they are fighting for, but my god they are fighting'; a remark that drew gasps of disbelief and disgust from many in the room. Lindisfarne was supported in this by members of the group RS21 (Revolutionary Socialism in the $21^{\text {st }}$ Century - a recent split from the SWP) which denounced the 'purism' of those leftists who failed to see that Islamist movements were forms of anti-Western resistance that had to be supported as part of an antimperialist politics in the UK. How Islamist groups can be described as 'antiimperialist' is something of a mystery to me. What might these people make of the role played by Saudi Arabia in promoting the violently puritanical Wahhabi Islam, which has provided the soil in which Islamist terror has flourished, and yet is a state which is closely allied to Britain and the US?

While an absurdity to the way Lindisfarne and her supporters would be so utterly unwelcome in the company of the people they are so ardently defending, I would argue that the work of Miller, Massoumi and Mills reflects a more cogent form of Left apologetics for the Islamic Right. David Miller, a Sociology Professor at the University of Bath, has researched corporate propaganda and lobbying and has written two books on this topic with William Dinan (Miller and Dinan, 2007 \& 2008). He was involved 
in the establishment of the public interest investigations website 'Spinwatch' in 2005, which describes itself as investigating 'key social, political, environmental and health issues in the UK and Europe' (http://www.spinwatch.org). Indeed there is much valuable research on this site and what is most concerning here is seeing an individual who has done valuable research into the areas of corporate lobbying and propaganda from a social justice perspective become involved in such torturous apologetics for the Islamic right. In his response to my questions at Historical Materialism, Miller offered an explicit defence of CAGE (formerly Caged Prisoners), an organisation set up by Moazzem Begg in 2003 as a support group for prisoners in Guantanamo Bay and Miller et al's argument in the piece entitled 'Apologists for terror or defenders of human rights? The Cage controversy in context', also published on the Open Democracy site (Miller et. al, June 2015) represents the fullest statement of their views.

This article characterises those questioning the politics of CAGE as representing another aspect of 'the more general assault on politically active Muslims and an attempt to push Muslim organisations to the margins of public life'. Yet it is notable throughout this article that the only politically active Muslims who are defended from this 'assault' are all extensively involved with right wing Islamist groups. Are there no other forums in which Muslims are politically active? These are certainly not deemed worthy of discussion by these writers. In examining the case against CAGE, Miller et al are drawn into the most torturous defence of 
Asim Qureshi, Research Director of Cage, who has continued to offer a quasi-defence of jihadist Mohammed Emwazi, known in the British tabloids as 'Jihadi John' who joined ISIS and was involved in a series of sadistic murders, and who was murdered in a drone attack in Syria in October 2015. Qureshi has gone on record describing Emwazi as 'extremely kind and gentle', though Miller et. al. rush to his defence insisting that he really meant Emwazi before he was 'radicalised'; indeed they appear happy to accept Quereshi's somewhat generous characterisation of Emwazi as essentially a victim of M15 and the security services. The article then moves to a discussion of Qureshi's support of the Muslim scholar Sheikh Haitham al-Haddad, who has written in defence of female genital mutilation, wife-beating, anti-Semitism and stoning for the 'crimes of adultery and homosexuality', and whom Querishi describes as 'one scholar in the UK that I think has an important contribution to make'. With studied neutrality, Miller et. al. comment that "there is no doubt that Haddad expresses a conservative strand of Islam, in particular on the appropriateness of punishment fitting the crime (Hudud) and on questions of sexuality". But one is left wondering as to exactly which of these human rights abuses Qureishi sees as representing that 'important contribution'.

In spite of this rigorous fairness toward a range of reactionary misogynist and homophobic Islamists, the real villains of the piece emerge in Miller et al's discussion of Southall Black Sisters and Gita Sahgal. CAGE's links with Amnesty International were notably criticised by Gita Sahgal. She was then head of the Gender Unit at Amnesty International and she 
criticised CAGE for promoting jihadi politics above the politics of human rights (http://freethinker.co.uk/2015/03/16/gita-sahgal-was-right/). Despite rejecting Sahgal's concerns at the time, these were subsequently proven, and Amnesty have now severed all links. For Miller et al this makes Gita Sahgal a 'cause célèbre for neoconservatives, the pro-war left and similar Islamaphobic groupings' rather than an advocate of human rights and feminism over Islamist reaction. Similarly Southall Black Sisters are characterised as part of a 'strange political convergence between radical feminist anti-racists and various Islamaphobic movements.' This statement by Miller et al builds on the distortions necessary to justify their argument throughout, demonising feminism at the same time. There is indeed nothing 'strange' about feminist resistance to religious repression, which one could well argue has been a major focus of feminist struggle from Mary Wollstonecraft's work in 1792 to the present day. There is also nothing strange or new about the pathologisation of this resistance by religious ideologists and their apologists, and indeed Dhaliwal and YuvalDavis' (2014) book on the legacy of the group Women Against Fundamentalism details these struggles extensively.

I would conclude with two points. The first is that David Miller's analysis, growing out of a concern with propaganda and representation, has become a form of politics in which the 'real' ceases to exist. The fact that there are young men and women who find something attractive in the oppositional identity offered by Islamist extremism and ISIS is a reality. This cannot be conjured away by shouting 'Islamaphobia' at organisations 
like British Muslims for a Secular Democracy and Southall Black Sisters which are genuinely trying to develop strategies to address this reality. But the work of Miller, Mills, Massoumi and Aked has no actual answer to this real problem. In their world, reality only exists as a binary of representation; you are either for or against 'Islamaphobia'. The incredibly dangerous implication of this was revealed at the Historical Materialism session when Miller stated that "Islamist is just another term for Muslim"; and in the way he here equates Muslims in general with Islamists, places him on exactly the same terrain as Donald Trump, the Sun newspaper and far right English Defence League, who all share the view of Muslim communities are undifferentiatedly in thrall to Islamist extremism and violence. While they see this as an expression of Muslim barbarism, Miller et al's view is simply a mirror image of this.

While there is justified concern with the way entire Muslim communities are characterised through the lens of 'security' and 'radicalisation', Miller et al are simply conjuring away the actual politics of the people they are defending. As writers like Karima Bennoune (2012) have pointed out using extensive documentary evidence, Islamic fundamentalism is itself based on the abuse of human rights. She demonstrates that the extent of the resistance to this, which is often led by women, and the way it is made up of people who are Muslims, atheists, secularists, and socialists. Gita Sahgal and SBS have been attacked because they reject this binary of 'Islam' vs 'The West' which is reproduced through both right wing and left wing narratives. SBS has consistently and 
indeed fearlessly stood up for a leftist, anti-racist, feminist secular politics. One might have thought that this would be the kind of politics one would expect to hear championed at a conference like Historical Materialism. Instead people were treated to a form of apology for organisations and an ideology that is directly involved in attacks and murders against the left, feminists, trade unionists and secularists which are taking place all over the world. There are some really important questions here that the British left needs to ask itself in deciding which side it is on.

Stephen Cowden has been involved in left, anti-racist and trade union activism and he has worked as Social Worker from 1992. In 2001 became a Social Work lecturer at Coventry University, teaching sociology and ethics. His research is concerned with Social Work ethics, Critical Pedagogy and the Sociology of Multiculturalism and Religious Fundamentalism. In 2013 he published (with Gurnam Singh) Acts of Knowing: Critical Pedagogy In, Against and Beyond the University.

\section{References}

Benson, O. (2015) 'Gita Saghal Was Right'. In The Freethinker. Available from: http://freethinker.co.uk/2015/03/16/gita-sahgal-was-right/ Bennoune, K. (2013) Your Fatwa Does Not Apply Here. New York: Norton Books.

Bhatt, C. (2006) 'The Fetish of the Margin: Religious Absolutism, AntiRacism and Postcolonial Silence'. New Formations No. 59.

Birchall, I. (2015) 'The Wrong Kind of Secularism'. Jacobin. Available from: https://www.jacobinmag.com/2015/11/charlie-hebdo-france-secularparis-attacks-lacite/

Chaturvedi, V. (ed) (2012) Mapping Subaltern Studies and the Postcolonial. London: Verso.

Chibber, V. (2013) Postcolonial Theory and the Specter of Capital. London: Verso. 
Dhaliwal, S. and Yuval-Davis, N. (eds) (2014) Women Against

Fundamentalism: Stories of Dissent and Solidarity. London: Lawrence \& Wishart.

Lindisfarne, N. and Neale, J. (2015) 'Oil Empires and Resistance in Iraq, Afghanistan and Syria'. Available from:

https://www.academia.edu/18629517/Oil Empires and Resistance in Afghanistan Iraq and Syria

Miller, D. \& Dinan W. (2008) A Century of Spin: How Public Relations Became the Cutting Edge of Corporate Power. London: Pluto Press.

Miller, D. \& Dinan W. (2007) Thinker, Faker, Spinner, Spy: Corporate PR and the Assault on Democracy. London: Pluto Press.

Muslim Brotherhood Review: Main Findings. (2015) House of Commons Report. Available from:

https://www.gov.uk/government/uploads/system/uploads/attachment data/file/486932/Muslim Brotherhood Review Main Findings.pdf [Accessed 27/5/16]

Miller, D., Mills, T., Massoumi, N. and Aked, H. (2015) 'The Five Pillars of Islamaphobia'. In openDemocracy. Available from:

https://www.opendemocracy.net/opensecurity/david-miller-tom-millshilary-aked-narzanin-massoumi/five-pillars-of-islamophobia

Miller D., Mills, T., Massoumi, N. (2015) 'Apologists for terror or defenders of human rights? The Cage controversy in context'. In openDemocracy. Available from:

https://www.opendemocracy.net/ourkingdom/tom-mills-narzaninmassoumi-david-miller/apologists-for-terror-or-defenders-of-human-righ

Quarashi, F. (2016) 'Prevent Gives People Permission to Hate Muslims: It has no place in Schools'. The Guardian. Available from:

http://www.theguardian.com/commentisfree/2016/apr/04/preventhate-muslims-schools-terrorism-teachers-reject [Accessed 30/5/16]

Said, E. (1978) Orientalism. London: Penguin.

Sell, H (2008) 'The Crisis in Respect'. In Socialism Today Issue 114.

Available from: http://www.socialismtoday.org/114/respect.html [Accessed 30/5/2008]

Shiraz Socialist. (2016) 'What Attitude should Socialists take to PREVENT'. Alliance for Workers Liberty. Available from:

https://shirazsocialist.wordpress.com/2016/03/03/what-attitude-shouldsocialists-take-to-prevent/ [Accessed 30/5/16] 


\section{Notes}

${ }^{1}$ Key texts in the development of Postcolonialism are the numerous works of Gayatri Spivak, and the Subaltern Studies group. Chaturvedi, V. (ed) (2012) Mapping Subaltern Studies and the Postcolonial offers a useful selection of key debates. For a more critical approach to Postcolonialism see Chibber, V (2013) Postcolonial Theory and the Specter of Capital.

2 PREVENT is described by the UK Government as 'about safeguarding people and communities from the threat of terrorism...It aims to stop people becoming terrorists or supporting terrorism' (http://www.Itai.info/what-is-prevent/). The PREVENT strategy has been controversial on the UK amongst the Left, with many groups characterising it as 'criminalising' or encouraging hostility to Muslims (see for e.g. Quarashi, F 'Prevent Gives People Permission to Hate Muslims' Guardian 4/4/16). However others have made the point that 'much of the opposition to Prevent stems not from "ordinary" parents and teachers, but is being organised and co-ordinated by ultra-reactionary Islamists, specifically Cage, Mend and their front organisation, Prevent Watch.'

(https://shirazsocialist.wordpress.com/2016/03/03/what-attitude-shouldsocialists-take-to-prevent/)

To cite this article:

Cowden, S. (2016). The Poverty of Apologism: The British Left, Feminism and the Islamic Right. Feminist Dissent, (1), 67-80. Retrieved from:

http://journals.warwick.ac.uk/index.php/feministdissent/article/view/13 